DOI: 10.38136/jgon.696818

\title{
Doğum İndüksiyonunda Dinoproston Peser Yerleştirilmesi Öncesi Vajinal Duşun Etkinliği, Bir Randomize Kontrollü Çalışma
}

\section{Efficacy Of Vaginal Douching Before The Application Of Dinoprostone Pessary In Labour Induction, A Randomized Controlled Study}

\author{
Banuhan ȘAHIN \\ Samettin ÇELIK \\ Canan SOYER ÇALIȘKAN ${ }^{2}$ \\ Șafak HATIRNAZ
}

(1) Orcid ID:0000-0002-8711-1584

(1) Orcid ID:0000-0002-6407-1129

(1) Orcid ID:0000-0002-9889-5249

(1) Orcid ID:0000-0001-8859-0639

\section{${ }^{1}$ Amasya University Sabuncuoglu Șerefeddin Training and Research Hospital, Gynecology and Obstetrics Department, Amasya, Turkey \\ ${ }^{2}$ Samsun Training and Research Hospital, Gynecology and Obstetrics Department, Samsun, Turkey \\ ${ }^{3}$ Medicana Samsun International Hospital, Gynecology and Obstetrics Department, Samsun, Turkey}

\section{Öz}

Amaç: Doğum indüksiyonu için vajene dinoproston peser yerleştirilmesi öncesi uygulanabilen vajinal duşun doğum ve yenidoğan sonuçlarına etkisini incelemek.

Materyal ve metod: Bu prospektif çalışmada doğum indüksiyonu yapılan 240 tekil, term gebe iki gruba randomize edildi. Vajinal duş ile dinoproston peser yerleştirilen grup $(n=103)$ ile vajinal duş olmaksızın dinoproston peser yerleştirilen grup ( $n=116$ ) birincil olarak vajen içi dinoproston yerleştirme süresi ikincil olarak vajen içine dinoproston yerleştirme başlangıcından aktif faza kadar olan süre, vajen içine dinoproston yerleştirme başlangııından serviksin tamamen açılmasına kadar geçen süre, indüksiyon intiyacı, doğum şekli (vajinal/sezeryan), ve uterus hiper-stimülasyonu yönünden karşılaştııılı. Doğum ağırıı̆ı, 5. Dakika Apgar skoru, entübasyon intiyacı, mekonyum varlığı, ve fetal enfeksiyon her iki grubun yenidoğanları arasında karşılaştırıldı. Veriler Student's-t test, Mann-Whitney U test and Pearson Chi-square test kullanılarak istatistiksel olarak karşılaştırıldı.

Bulgular: Vajinal duş ile vajen içine dinoproston peser yerleştirilen grubun dinoproston aplikasyon süresi ( $p=0.001)$, dinoproston peser aplikasyonu başlangıcından aktif faza kadar olan süre $(p=0.001)$ ve dinoproston peser aplikasyonu başlangııından serviksin tamamen açılmasına kadar geçen süre $(p=0.001)$ vajinal duş yapılmayan gruba göre daha kısaydı. Doğum şekli gruplar arasında istatistiksel farklllık göstermiyordu ( $p=0.414$ ). Uterus hiper-stimülasyonu vajinal duş yapılan grupta daha fazla olsa da istatistiksel anlama ulaşmamaktaydı $(p=0.058)$. Yenidoğan ortalama ağırlığı ve 5 . Dakika Apgar skoru vajinal duş yapılan grupta daha fazlaydı ( $p=0.660,0.091)$, fakat entübasyon intiyacı, mekonyum varlığı, ve fetal enfeksiyon oranı istatistiksel anlamda daha düşüktü (sırasıly $p=0.007,0.018,0.011$ ).

Sonuç: Uygulaması güvenli, kolay ve ucuz bir prosedür olan vajen içi dinoproston peser aplikasyonu öncesi vajinal duş, anne ve fetal olumsuz sonuçlara yol açmaksızın kadınlarda doğum indüksiyonunu hızlandırabilir.

Anahtar kelimeler: dinoproston, doğum indüksiyonu, vajinal duş.

\begin{abstract}
Aim: To investigate the effects on delivery and neonatal outcomes of vaginal douching, which can be performed before the application of dinoprostone pessary in the vagina for labour induction.

Materials and Method: In this prospective study 240 women with singleton, term pregnancy who underwent labour induction, were randomized into two groups. Application of dinoprostone pessary intra-vaginally with vaginal douching group $(n=103)$ and it without vaginal douching group $(n=116)$ were compared firstly for duration of dinoprostone application intra-vaginally secondly for duration from the beginning of dinoprostone application intra-vaginally to the active phase of labor, duration from the beginning of dinoprostone application intra-vaginally to total cervical dilatation, induction need, route of delivery (vaginal/cesarean), and uterine hyperstimulation. The birth weight, 1 and 5-minute Apgar scores, intubation need, NICU admission, presence of meconium, and fetal infection were compared between the newborns of the two groups. Data were statistically compared using the Student's-t test, Mann-Whitney U test and Pearson Chi-square test.
\end{abstract}

Results: Intra-vaginal dinoprostone pessary application with vaginal douching compared it without douching had shorter duration of dinoprostone application $(p=0.001)$, duration from the beginning of dinoprostone application to the active phase of labor $(p=0.001)$ and duration from the beginning of dinoprostone application to total cervical dilatation $(p=0.001)$. Route of delivery was not statistically different between the groups $(\mathrm{p}=0.414)$. Uterine hyperstimulation was more frequent in the vaginal douche group however it did not reach the statistical significance $(p=0.058)$. Neonatal mean birth weight and 5-minute Apgar scores were higher in the vaginal douching group $(p=0.660,0.091)$ while intubation need, presence of meconium, and fetal infection rates were lower with statistical significance ( $p=0.007,0.018,0.011$, respectively).

Conclusion: As a safe, easy to perform and cheap procedure, vaginal douching prior to dinoprostone pessary application intra-vaginally can augment the induction of labour in women without increasing maternal or fetal adverse outcomes.

Keywords: dinoprostone, labour induction, vaginal douching.

Sorumlu Yazar/ Corresponding Author: 


\section{INTRODUCTION}

Labour induction is a common method used in obstetric practice for vaginal delivery in cases where antenatal follow-up has no more benefit on maternal and fetal health. Various mechanical or pharmacological agents can be used to induce cervical maturation and ripening in order to initiate labour (1). One of the most widely-used agents is Dinoprostone, a prostaglandin E2 derivative used in labor induction, which helps the development of cervical maturation and induces uterine contractions via prostaglandin E2 (PGE2) receptors (2). PGE2 exerts its action by increasing the local collagenase, elastase, glycosaminoglycan, dermatan sulphate and hyaluronic acid activities in the cervix and provides cervical effacement and dilatation (3). Dinoprostone can be used in various forms, such as vaginal gel, tablet and slow release pessary (Propess $®$ ).

The clinical efficacy of dinoprostone pessary administration for labor induction may vary according to the vaginal micro-environmental factors as humidity and $\mathrm{pH}$ in pregnant women $(4,5)$. They regulates the activity of vaginal prostaglandins and affects the absorption and metabolism of PGE2, thereby causing differences in the clinical activity of the drug (6). However, factors such as infections of the lower genital tract, bacterial vaginosis, semen, vaginal douching and amniotic fluid may alter the dissolution of dinoprostone pessary in the vagina (7). Impaired dinoprostone release due to these differences may result in alterations of the duration and route of delivery in clinical practice (8).

Vaginal douching is known to cause decreased acidity by dilution of vaginal normal discharge and a tendency to alkali $\mathrm{pH}$ by removing the lactobacilli mechanically in the vaginal microenvironment $(9,10)$. Yayla et al. claimed that women with vaginal dinoprostone administration following vaginal douching had a more rapidly induced labour compared to women with no vaginal douching for labour induction (11).

The aim of this study was to investigate the effect on delivery and neonatal outcomes of vaginal douching, which can be performed easily in clinical practice before the intra-vaginal application of dinoprostone pessary for labour induction.

\section{MATERIALS AND METHODS}

The study included 268 pregnant women with planned labour induction between 1 June 2018 and 1 December 2018 in Samsun Women and Children's Health Research and Training Hospital. Approval for the study was granted by the Local Ethics Committee (decision no: 09.2019.127) All participants were informed about the study and written consent was obtained from each.

The patients included were pregnant women, aged 18-42 years, with a single live pregnancy, gestational week $\geq 38$ weeks, and vertex presentation, with no spontaneous uterine contractions or insufficient Bishop's score $\leq 4$. The exclusion criteria were set as membrane rupture ( 13 cases), suspicion of chorioamnionitis (10 cases), and multiple pregnancy (5 cases). The indications approved for labour induction were post-term $(\geq 42+0)$ gestational week, oligohydramnios, intrauterine growth restriction, diabetes mellitus, and pre-eclampsia with $\geq 37$ weeks.

The study group comprised 103 women who were administered dinoprostone (Propess $®$, Ferring, England, slow release system of 10 mg PGE2) intravaginal application following vaginal douching with sterile $0.9 \% \mathrm{NaCl}$ serum (10 cc) for labour induction. The control group was formed of 116 women who were administered Propess $₫$ without vaginal douching. The group allocations were made according to a computer-generated randomization procedure. The demographic data of all pregnant women who were admitted to the delivery room were recorded and ultrasonography and cardiotocography examinations were performed. The initial cervical assessment and Bishop score calculation were provided by two doctors who were blinded to study group allocation. With the onset of active labour, fetal heart rate and uterine myometrial activity were monitored continuously.

The duration of dinoprostone application in the posterior fornix of the vagina was calculated as the time from insertion to manual removal of the agent because of hyperstimulation or successful labour induction confirmed by vaginal examination (4 cm dilatation and $60 \%$ effacement of cervix) (12). Tachysystole was defined as at least six contractions for two consecutive 10-minute periods. Hyperstimulation syndrome was defined as the presence of tachysystole associated with non-reassuring FHR patterns (13). When an adequate labour pattern was not obtained despite dinoprostone, an oxytocin (Synpitan®, Deva, Turkey) infusion was started for an adequate contraction pattern of uterus.

Primary outcome was the duration of dinoprostone application intra-vaginally which indicates successful labour induction. The active phase of labour was accepted as from the time of $5 \mathrm{~cm}$ dilatation of the cervix with regular uterine contractions to the time of total cervical dilatation (12). Secondary outcomes were the duration from the beginning of dinoprostone application intra-vaginally to the active phase of labor, the duration from the beginning of dinoprostone application intra-vaginally to total cervical dilatation, induction need, route of delivery (vaginal/cesarean), and uterine hyperstimulation. The newborns of both groups were compared in respect of birth weight, 5-minute Apgar scores, intubation need, presence of meconium, and fetal infection.

Statistical analysis: The sample size was calculated to be 96 with a 1:1 ratio with $80 \%$ power and $5 \%$ margin of error, and the mean duration from agent application to active phase onset was assumed to be $13.77 \mathrm{~h}$ in the study group and $18.25 \mathrm{~h}$ in the control group according to a previously published study (11).

Data obtained in the study were analysed statistically using NCSS 2007 software (Number Cruncher Statistical System, Kaysville, Utah, USA). Descriptive statistical methods (mean, standard deviation, median, frequency, percentage, minimum, maximum) were used to evaluate study data. Conformity to normal distribution of quantitative data was assessed using the Shapiro-Wilk test and graphic studies. The between-group comparisons of quantitative data with normal distribution were made using the Student's-t test, and the Mann Whitney U-test was applied to data that did not conform to normal distribution. The Pearson Chi-square test were used in the comparisons of qualitative data. A value of $p<0.05$ was accepted as statistically significant.

\section{RESULTS}

The patient flow chart is listed in detail in Figure 1

\section{Figure 1}

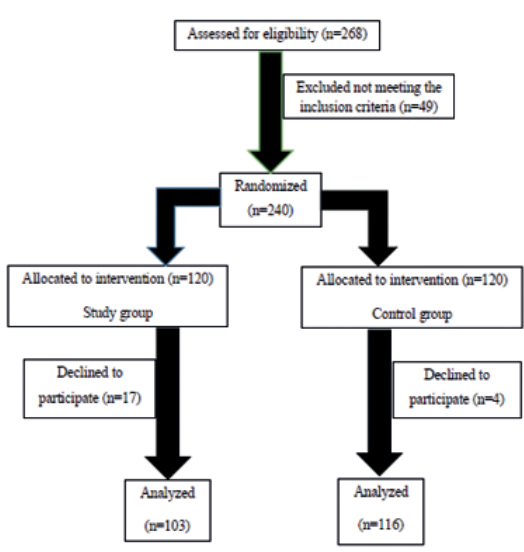


Of the initial 268 women, 28 were excluded from the study because they did not meet the inclusion criteria. Two hundred and forty participants were randomly assigned to the study group of 120 women who had vaginal douching before dinoprostone passery application and the control group of 120 women who received it without vaginal douching. Seventeen women in the study group and four women in control group were excluded because they declined to participate in the study.

The descriptive characteristics of groups are summarized in Table 1. There was no statistically significant difference between the groups in respect of the induction indications and initial Bishop scores $(p>0.05)$.

Table 1: Descriptive characteristics of the groups according to whether or not vaginal douching before application of dinoprostone intra-vaginally.

\begin{tabular}{|llll|}
\hline$(-)(\mathrm{n}=116)$ & \multicolumn{3}{c|}{ Vaginal Douche } \\
& $(+)(\mathrm{n}=103)$ & P-value & \\
\hline Age (years) & $26.66 \pm 6.12$ & $25.36 \pm 4.54$ & ${ }^{\mathrm{a}} 0.073$ \\
Gestational age & $39.64 \pm 2.03$ & $40.26 \pm 1.52$ & ${ }^{\mathrm{b}} 0.062$ \\
(weeks) & & & \\
Gravidity & $1-3(1)$ & $1-3(1)$ & ${ }^{\mathrm{b}} 0.609$ \\
Parity & $0-2(0)$ & $0-2(0)$ & ${ }^{\mathrm{b}} 0.388$ \\
$\quad$ Primiparous & $63(54.3 \%)$ & $49(47.6 \%)$ & ${ }^{\mathrm{c}} 0.319$ \\
$\quad$ Multiparous & $53(45.7 \%)$ & $54(52.4 \%)$ & \\
Abortion & $0-3(0)$ & $0-5(0)$ & ${ }^{\mathrm{b}} 0.232$ \\
Induction indica- & & & ${ }^{\mathrm{c}} 0.423$ \\
$\quad$ & & \\
$\quad$ tions Postterm & $64(55.2 \%)$ & $58(56.3 \%)$ & \\
Oligohydramnios & $13(11.2 \%)$ & $15(14.6 \%)$ & \\
$\quad$ IUGR & $17(14.7 \%)$ & $10(9.7 \%)$ & \\
Diabetes mellitus & $16(13.8 \%)$ & $10(9.7 \%)$ & \\
$\quad$ Preeclampsia & $6(5.2 \%)$ & $10(9.7 \%)$ & \\
Initial Bishop score & $1-3(3)$ & $1-3(3)$ & ${ }^{\mathrm{b}} 0.111$ \\
\hline
\end{tabular}

VD: vaginal delivery, $C D$ : Cesarean delivery. Variables presented as mean $\pm S D, \min -m a x$ (median) and $n(\%)$. aStudent-t Test, bMann Whitney U Test, cPearson Chi-Square Test. ${ }^{*} p<0.05$; ${ }^{* *} p<0.01$

The duration of dinoprostone application in the posterior fornix of vagina, the duration from the beginning of dinoprostone application intra-vaginally to the active phase of labor, the duration from the beginning of dinoprostone application intra-vaginally to total cervical dilatation were statistically significantly shorter in the vaginal douching group than in the group without vaginal douching $(p<0.001)$. Induction need was lower in the vaginal douching group compared to control group $(p<0.001)$. There was no statistically significant difference between the groups in respect of the route of delivery $(p=0.414)$. While uterine hyperstimulation was more frequent in the vaginal douching group, the difference between the groups did not reach statistical significance $(p=0.058)$ (Table 2). The neonatal outcomes of the groups are presented in Table 2. The intubation need, presence of meconium and fetal infection rates were lower in the group with vaginal douche before dinoprostone pessary ( $p=0.018, p=0.018, p=0.011$, respectively).

Table 2: Labour and neonatal outcomes of the groups according to whether or not vaginal douching before application of dinoprostone intra-vaginally.

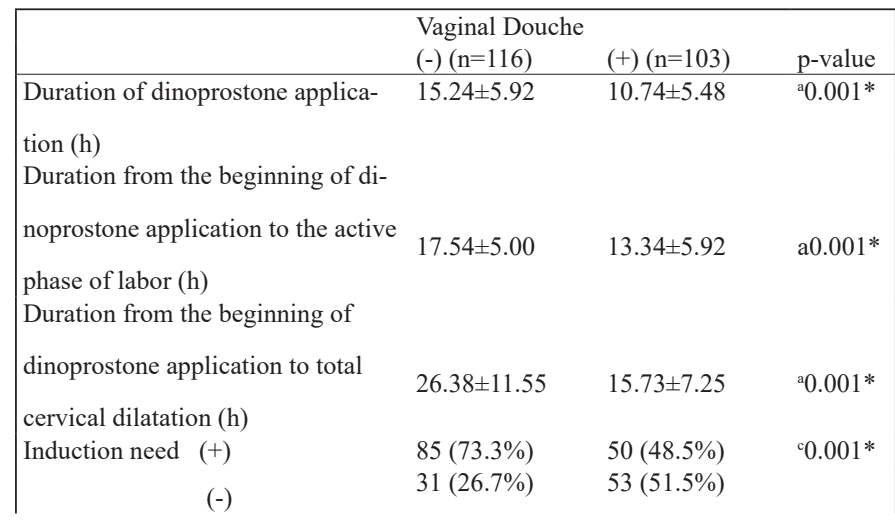

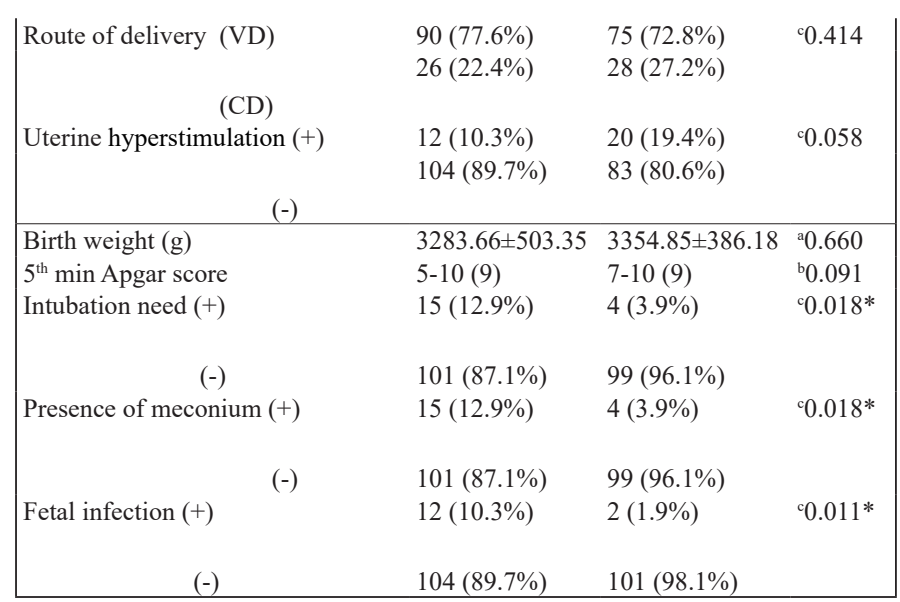

VD: vaginal delivery, $C D$ : Cesarean delivery. Variables presented as mean $\pm S D$, min-max (median) and $n(\%)$. aStudent-t Test, bMann Whitney U Test, cPearson Chi-Square Test. ${ }^{*} p<0.05 ;{ }^{* *} p<0.01$.

\section{DISCUSSION}

The efficacy of intravaginal dinoprostone in labour induction between groups of women with and without vaginal douching before pessary application was investigated in this prospective randomized controlled study. The results of this study showed that favorable maternal and neonatal outcomes were in the vaginal douching group. The duration of dinoprostone application in the posterior fornix of vagina, the duration from the beginning of dinoprostone application intra-vaginally to the active phase of labor, the duration from the beginning of dinoprostone application intra-vaginally to total cervical dilatation was significantly shorter in the study group than the control group. The newborns of the women who had faster delivery following dinoprostone pessary and vaginal douching, had a lesser need for intubation, lower rates of presence of meconium, and fetal infection compared to women without vaginal douching prior to dinoprostone pessary application.

The vaginal humidity changes continuously throughout the lifetime of a woman, depending on hormonal and environmental factors. Vaginal douching with $\mathrm{NaCl}$ serum increases the efficiency of dinoprostone in the vagina by dilution of the normal vaginal discharge and mechanical removal of lactobacilli colonization. Döderlein bacilli in a healthy vagina produce lactic acid by consuming glycogen and keep the vagina $\mathrm{pH}$ acidic (3.8-4.5). However, an alkaline $\mathrm{pH}$ impairs the healthy endogenous vaginal microbiota and stimulates the reproduction of the pathogenic bacteria (14). Thus, when the vaginal $\mathrm{pH}$ is altered, the absorption and metabolism of drugs applied intra-vaginally may be changed and this may result in modifications of their effects $(15,16)$. In women administered vaginal dinoprostone for labour induction, the duration of active phase delivery has been shown to be shorter in a higher $\mathrm{pH}$ environment compared to a lower $\mathrm{pH}$ environment and a higher vaginal $\mathrm{pH}$ has been reported to enhance the functions of prostaglandin tablets and shorten the active phase of labor (17).

Vaginal douching decreases the density of vaginal flora components and changes the vaginal dissolution of dinoprostone agent (18). This change to a well absorbable environmental status provides the faster onset of dinoprostone activity as a result of vaginal douching. It was observed in the current study that pregnant women applied with vaginal douching prior to dinoprostone intra-vaginal application had faster labour compared to the pregnant women without vaginal douching. The increased bioavailability of agent occurring as a result of vaginal douching can be considered to have decreased the duration of dinoprostone pessary application in the posterior fornix of the vagina, the duration from the beginning of dinoprostone application intra-vaginally to the active phase of labor, the duration from the beginning of dinoprostone 
application intra-vaginally to total cervical dilatation and the need for induction. With the increasing activity of dinoprostone, uterine hyperstimulation was also increased in the pregnant women with vaginal douching, although the difference between the groups did not reach statistical significance.

Increased vaginal concentrations of PGE2 caused by uncontrolled labour induction interventions could result in uterine tachysystole (hyperstimulation). Increased meconium status, increased cesarean delivery rates and low Apgar scores may be encountered due to unfavorable fetal heart rates accompanying this condition (19). In the current study, higher uterine hyperstimulation rates were observed in the pregnant women with vaginal douching prior to dinoprostone application, although this did not worsen the neonatal outcomes. Cesarean delivery rates and chorioamnionitis risks are known to be higher in pregnant women with a prolonged first stage of labour (20). In the current study, fetal infections were less common in pregnant women with vaginal douching prior to dinoprostone application due to the shortening of the first stage of labour.

A limitation of this study is that the vaginal $\mathrm{pH}$ value was not assessed objectively in the pregnant women with and without vaginal douching before and after dinoprostone pessary admission, therefore the exact vaginal $\mathrm{pH}$ values of the women were not known. In future research, pH assessment should be performed to detect the optimal vaginal $\mathrm{pH}$ for dinoprostone efficacy in labor induction.

In conclusion, the results of this study have shown that vaginal douching prior to intra-vaginal dinoprostone application may augment the bioavailability of dinoprostone by increasing the vaginal humidity and $\mathrm{pH}$. For pregnant women with planned labour induction, vaginal douching can be easily performed before intravaginal dinoprostone pessary application and it can provide safe and rapid labor.

\section{Acknowledgments}

The abstract of this study was presented orally at the Karadeniz Gynecology and Obstetrics Congress, Samsun, on 07.04.2019 (OP no: 32).

\section{Disclosure of interest}

The authors report no conflict of interests.

\section{REFERENCES}

1. Chowdhary A, Bagga R, Jasvinder Kalra, Jain V, Saha SC, Kumar P. Comparison of intracervical Foley catheter used alone or combined with a single dose of dinoprostone gel for cervical ripening: a randomised study. J Obstet Gynaecol. 2019;39:461-7.

2. Yount SM, Lassiter N. The Pharmacology of Prostaglandins for Induction of Labor. Vol. 58, J Midwifery Womens Health. 2013. p. 133-44.

3. Bakker R, Pierce S, Myers D. The role of prostaglandins E1 and E2, dinoprostone, and misoprostol in cervical ripening and the induction of labor: a mechanistic approach. Arch Gynecol Obstet. 2017;296:167-79.

4. Lyrenäs $S$, Clason I, Ulmsten U. In vivo controlled release of PGE2 from a vaginal insert $(0.8 \mathrm{~mm}, 10 \mathrm{mg})$ during induction of labour. BJOG. 2001;108:169-78.

5. Basirat Z, Barat SH, Ghanbarpour A, Golsorkhtabar-Amiri M. Does vaginal $\mathrm{pH}$ affect the efficacy of dinoprostone in cervical ripening/labor duration? Clin Exp Obstet Gynecol. 2012;39:522-5.

6. Johnson TA, Greer IA, Kelly RW, Calder AA. The effect of $\mathrm{pH}$ on release of PGE2 from vaginal and endocervical preparations for induction of labour: an in[vitro study. Br J Obstet Gynaecol. 1992;99:877-80.

7. Godha K, Tucker KM, Biehl C, Archer DF, Mirkin S. Human vaginal pH and microbiota: an update. Vol. 34, Gynecol Endocrinol. 2018. p. 451-5.
8. Taylor AV, MacKenzie IZ. The effect of $\mathrm{pH}$ on release of PGE2 from vaginal and endocervical preparations for induction of labour. $\mathrm{Br} \mathrm{J}$ Obstet Gynaecol. 1993;100:500-1.

9. Martino JL, Vermund SH. Vaginal douching: Evidence for risks or benefits to women's health. Vol. 24, Epidemiol Rev. 2002. p. 109-24.

10. Ramsey PS, Ogburn PL, Harris DY, Heise RH, DiMarco CS, Ramin KD. Effect of vaginal $\mathrm{pH}$ on efficacy of the controlled-release dinoprostone vaginal insert for cervical ripening/labor induction. J Matern Fetal Neonatal Med. 2003;13:250-3.

11. Yayla AÇ, Kurek EM, Ozkaya E, Yenidede I, Bostanci EE, Kilicci C, et al. Effect of vaginal washing before intravaginal dinoprostone insertion for labor induction: A randomized clinical trial. J Obstet Gynaecol Res. 2018;44:214955.

12. Zhang J, Troendle J, Mikolajczyk R, Sundaram R, Beaver J, Fraser W. The natural history of the normal first stage of labor. Obstet and Gynecol 2010; 115(4): 705-710.

13. Shetty A, Mackie L, Danielian P, Rice P, Templeton A. Sublingual compared with oral misoprostol in term labour induction: A randomised controlled trial. BJOG. 2002;109:645-50.

14. Willhite LA, O'Connell MB. Urogenital atrophy: Prevention and treatment. Vol. 21, Pharmacotherapy 2001. p. 464-80.

15. Önen Ş, Özakşit G, Yilmaz B, Güngör T, Bilge Ü, Süt N, et al. The role of vaginal $\mathrm{pH}$ on efficacy of controlled-release dinoprostone vaginal insert for cervical ripening/labor induction: A prospective double-blind study. J Turkish German Gynecol Assoc. 2008;9:206-11.

16. Ramsey PS, Ogburn PL Jr, Harris DY, Heise RH, Ramin KD. Effect of vaginal $\mathrm{pH}$ on efficacy of the dinoprostone gel for cervical ripening/labor induction. Am J Obstet Gynecol. 2002;187:843-6.

17. Singh U, Mehrotra S, Gupta HP, Dhakad A, Jain V. A prospective double blind trial investigating impact of vaginal $\mathrm{pH}$ on efficacy of prostaglandin gel for cervical ripening and course of labour. J Obstet Gynaecol. 2011;31:217-9.

18. Yanikkerem E, Yasayan A. Vaginal douching practice: Frequency, associated factors and relationship with vulvovaginal symptoms. J Pak Med Assoc. 2016;66:387-92.

19. Ahmed Al, Zhu L, Aldhaheri S, Sakr S, Minkoff H, Haberman S. Uterine tachysystole in spontaneous labor at term. J Matern Fetal Neonatal Med. 2016;29:3335-9.

20. Cheng YW, Shaffer BL, Bryant AS, Caughey AB. Length of the first stage of labor and associated perinatal outcomes in nulliparous women. Obstet Gynecol. 2010;116:1127-35. 